\title{
Determination of the Gas-Phase Acidity of Methylthioacetic Acid Using the Cooks' Kinetic Method
}

\author{
Jianhua Ren and Chirag G. Patel \\ Department of Chemistry, University of the Pacific, Stockton, California, USA
}

We determined the gas-phase acidity of methylthioacetic acid (MTA) in a triple-quadrupole mass spectrometer using the Cooks' kinetic method with the consideration of entropy effects. The negatively charged proton-bound dimers were generated by electrospray ionization. Collisioninduced dissociation was applied to the dimer ions and the product ion ratios were measured at four different collision energies. The gas-phase acidity $\left(\Delta H_{\text {acid }}\right)$ of MTA was determined to be 340.0 $\pm 1.7 \mathrm{kcal} / \mathrm{mol}$ using the extended kinetic method and $339.8 \pm 1.7 \mathrm{kcal} / \mathrm{mol}$ using the standard kinetic method. The entropy term is insignificant in this case and can be ignored. The standard kinetic method yielded a free energy of deprotonation of MTA $\left(\Delta G_{\text {acid }}\right)$ of $333.0 \pm 1.7 \mathrm{kcal} / \mathrm{mol}$. The entropy of the acid dissociation, $\Delta S_{\text {acid }}$, was estimated to be $22.8 \mathrm{cal} / \mathrm{mol} \mathrm{K}$. Theoretical prediction at the B3LYP/6-31 $+\mathrm{G}^{*}$ level of theory gives a similar value for $\Delta H_{\text {acid }}$ of 338.9 $\mathrm{kcal} / \mathrm{mol}$. In the gas-phase, MTA is a stronger acid than methoxyacetic acid, although in solution, MTA is a weaker one. (J Am Soc Mass Spectrom 2005, 16, 535-541) (C 2005 American Society for Mass Spectrometry

$\mathrm{M}$ ethylthioacetic acid (MTA), $\mathrm{CH}_{3} \mathrm{SCH}_{2} \mathrm{CO}_{2} \mathrm{H}$, is an important sulfur-containing compound involved in a variety of chemical and biological reactions. MTA has been used as a unique reagent in the synthesis of sulfur containing ketones [1, 2], and as a model to study electron-transfer reactions in substituted alkyl sulfides [3]. A recent study of natural food flavors found that MTA is one of the biotransformation products of the cysteine-aldehyde conjugate by baker's yeast [4]. MTA has a similar structure as that of methoxyacetic acid, $\mathrm{CH}_{3} \mathrm{OCH}_{2} \mathrm{CO}_{2} \mathrm{H}$. Both methoxyacetic acid and MTA have been used to study solvent and substituent effects on the acidity of substituted acetic acids [5, 6]. In aqueous solution, MTA ( $\left.\mathrm{p} K_{\mathrm{a}}=3.7\right)$ is a slightly weaker acid than methoxyacetic acid $\left(\mathrm{p} K_{\mathrm{a}}=3.5\right)$ [6]. In the gas-phase, methoxyacetic acid has an acidity $\left(\Delta H_{\text {acid }}\right)$ of $341.9 \mathrm{kcal} / \mathrm{mol}[7,8]$, while the acidity of MTA is unknown. In this paper, we report on the first determination of the gas-phase acidity of MTA by using the Cooks' kinetic method $[9,10]$ and theoretical calculations.

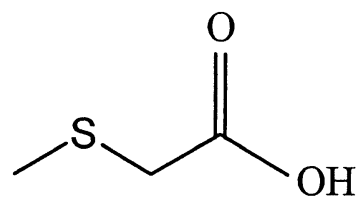

MTA

Published online February 12, 2005

Address reprint requests to Dr. J. Ren, Department of Chemistry, University of the Pacific, 3601 Pacific Avenue, Stockton, CA 95211, USA. E-mail: jren@pacific.edu

\section{Experimental}

The gas-phase acidity $\left(\Delta H_{\text {acid }}\right)$ of MTA was determined by using the extended Cooks' kinetic method in which entropy effects were taken into consideration [11-13]. Selected applications of using the extended kinetic method to determine thermochemical quantities can be found in the current literature [14-19]. Briefly, a series of proton-bound dimers $\left(\left[\mathrm{A} \cdot \mathrm{H} \cdot \mathrm{A}_{\mathrm{i}}\right]^{-}\right)$of deprotonated MTA (HA) with a set of conjugate bases of reference acids $\left(\mathrm{HA}_{\mathrm{i}}\right)$ were generated in the mass spectrometer. The reference acids all have known gas-phase acidities. Each proton-bound dimer was activated by collisions with argon atoms and underwent competitive unimolecular dissociations to produce two ionic products, $\mathrm{A}^{-}$ and $\mathrm{A}_{\mathrm{i}}^{-}$, with rate constants of $k$ and $k_{\mathrm{i}}$, respectively, Scheme 1.

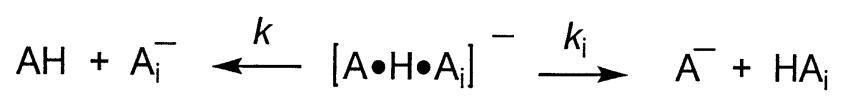

Scheme 1

With the assumption that there are no reverse activation barriers for both dissociation channels, the natural logarithm of the ratio of the rate constants can be expressed by eq 1 , where $R$ is the ideal gas constant, $T_{\text {eff }}$ is the effective temperature of the activated dimer ion, and $\Delta H$ and $\Delta H_{\mathrm{i}}$ are the gas-phase acidities of MTA and the reference acid, respectively. Although there are different explanations of the concept of the effective temperature [20-24], the conventional view is that the observed branching ratio of the product ions corre- 
sponds to the dissociation of a proton-bound dimer with a Boltzmann distribution for the internal energy with the temperature at $T_{\text {eff }}[10,25]$. The term $\Delta(\Delta S)$ is the difference of the activation entropies between the two competing dissociation channels. The ratio of the rate constants $\left(k / k_{\mathrm{i}}\right)$ can be assumed to be equal to the ratio of the intensities of the product ions $\left(\left[\mathrm{A}^{-}\right] /\left[\mathrm{A}_{\mathrm{i}}^{-}\right]\right)$, if secondary fragmentation is negligible. In order to have a proper statistical treatment of the uncertainty in the data analysis, the average gas-phase acidity of the

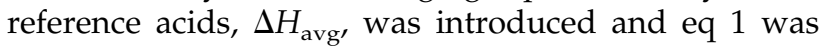
converted to eq 2 , where $\ln \left(\left[\mathrm{A}^{-}\right] /\left[\mathrm{A}_{\mathrm{i}}^{-}\right]\right)$has a linear relationship with $\Delta H_{\mathrm{i}}-\Delta H_{\mathrm{avg}}$ [26]. For deriving $\Delta H$, the proton-bound dimers will be activated at several different collision energies and the values of $\left[\mathrm{A}^{-}\right] /\left[\mathrm{A}_{\mathrm{i}}^{-}\right]$will be measured at each collision energy. Two thermokinetic graphs can be generated from eq 2 . The first graph consists of linear plots of $\ln \left(\left[\mathrm{A}^{-}\right] /\left[\mathrm{A}_{\mathrm{i}}^{-}\right]\right)$versus $\Delta H_{\mathrm{i}}-\Delta H_{\mathrm{avg}}$ with $1 / R T_{\text {eff }}$ as the slope and $-[(\Delta H-$ $\left.\left.\Delta H_{\text {avg }}\right) / R T_{\text {eff }}-\Delta(\Delta S) / R\right]$ as the intercept. The second graph is the plot of $\left[\left(\Delta H-\Delta H_{\text {avg }}\right) / R T_{\text {eff }}-\Delta(\Delta S) / R\right]$ obtained from the first graph versus $-1 / R T_{\text {eff }}$ and a Van't Hoff-like plot can be generated with a slope of $\Delta H$ $-\Delta H_{\text {avg }}$ and an intercept of $-\Delta(\Delta S) / R$. If the two competing channels have a similar entropy at their transition states, then the $\Delta(\Delta S)$ term is negligible and this leads to the validation of the standard kinetic method, eqs 3 and 4 , where $\Delta G$ and $\Delta G_{i}$ are the gas-phase deprotonation free energies of MTA and the reference acid $[9,27,28]$. In this case, the values of $\Delta H$ and $\Delta G$ can simply be determined as the ratios of the negative intercepts to the slopes from eq 3 and 4, respectively. The cancellation of the entropy term requires that the two components of the proton-bound dimer are similar in structure.

$$
\begin{aligned}
\operatorname{In}\left(k / k_{i}\right)=\Delta H_{i} / R T_{\text {eff }}-\left[\Delta H / R T_{\text {eff }}-\Delta(\Delta S) / R\right] & \\
\operatorname{In}\left(\left[\mathrm{A}^{-}\right] /\left[A_{\mathrm{i}}^{-}\right]\right)= & \left(\Delta H_{\mathrm{i}}-\Delta H_{\text {avg }}\right) / R T_{\text {eff }} \\
& -\left[\left(\Delta H-\Delta H_{\text {avg }}\right) / R T_{\text {eff }}-\Delta(\Delta S) / R\right] \\
\operatorname{In}\left(\left[\mathrm{A}^{-}\right] /\left[A_{\mathrm{i}}^{-}\right]\right)= & \Delta H_{\mathrm{i}} / R T_{\text {eff }}-\Delta H / R T_{\text {eff }} \\
\operatorname{In}\left(\left[\mathrm{A}^{-}\right] /\left[A_{\mathrm{i}}^{-}\right]\right)= & \Delta \mathrm{G}_{\mathrm{i}} / R T_{\text {eff }}-\Delta \mathrm{G} / R T_{\text {eff }}
\end{aligned}
$$

The experiments were carried out using a triple quadrupole mass spectrometer (Varian 1200L) located in the Mass Spectrometry Center of the Chemistry Department at the University of the Pacific. The instrument consists of a near horizontal electrospray ionization (ESI) source with the nitrogen drying gas flowing through a capillary, a hexapole ion guide with a pressure of about $1 \mathrm{mTorr}$ and a triple quadrupole mass analyzer with a curved collision chamber. Ions generated in the ESI source are presumably thermalized by multiple collisions with the bath gas molecules in the ion guide chamber. The voltage of the ESI needle was set at $-4.5 \mathrm{kV}$ and the drying gas temperature was set at $150^{\circ} \mathrm{C}$. The first important step for carrying out the acidity measurement was to generate stable protonbound dimer ions of deprotonated MTA with the conjugate bases of selected reference acids. Each proton-bound dimer was formed by an infusion of a solution of methanol and water (50:50, vol/vol) containing a mixture of MTA and a reference acid $\left(10^{-5}-10^{-4} \mathrm{M}\right)$ into the ESI (negative mode) chamber at a flow rate of $10-20 \mu \mathrm{L} / \mathrm{min}$. The signal of the dimer was optimized by adjusting the instrument conditions, especially the capillary voltage. In most cases the capillary voltage was set at around $20 \mathrm{~V}$. The dimer ion was isolated with the first quadrupole and was subjected to collision-induced dissociation (CID) in the collision chamber with argon as the collision gas $(0.50$ $\pm 0.03 \mathrm{mTorr})$. The dissociation product ions were analyzed by the third quadrupole. In order to examine the possible secondary fragmentations, a CID spectrum with a wider range of $m / z$ values was taken for each protonbound dimer at several collision energies and no secondary fragments were observed. The CID product ion intensities were measured by setting the instrument in a single reaction monitoring (SRM) mode in which the scan was focused on the selected product ions. Multiple measurements were performed at different days. The results were repeatable with a relative uncertainty within $\pm 5 \%$. For each proton-bound dimer, the CID experiment was carried out at four different collision energies, 1.0, 1.5, 2.0, and $2.5 \mathrm{eV}$, in the center-of-mass frame $\left(E_{\mathrm{cm}}\right)$. The center-ofmass energy was calculated using the equation: $E_{\mathrm{cm}}=$ $E_{\mathrm{lab}}[\mathrm{m} /(\mathrm{M}+\mathrm{m})]$, where $E_{\mathrm{lab}}$ is the collision energy in laboratory frame, $\mathrm{m}$ is the mass of argon and $\mathrm{M}$ is the mass of the proton-bound dimer ion.

All chemicals were purchased from Aldrich Chemical Co. (Milwaukee, WI) and were used without further purification.

Theoretical calculations were carried out using the Gaussian 98 suite of programs [29]. The hybrid density functional theory at the B3LYP/6-31 + $\mathrm{G}^{*}$ level was employed to calculate the geometries and the vibrational frequencies. Thermochemical quantities (the sum of the electronic enthalpies at $298 \mathrm{~K}$ ) were obtained from the frequency calculations and no scaling was applied to the calculated frequencies. Theoretical gas-phase acidities were derived using an isodesmic reaction (eq 5) with methoxyacetic acid, $\mathrm{CH}_{3} \mathrm{OCH}_{2} \mathrm{CO}_{2} \mathrm{H}$, serving as the reference standard.

$$
\mathrm{HA}+\mathrm{CH}_{3} \mathrm{OCH}_{2} \mathrm{CO}_{2}^{-} \rightarrow \mathrm{A}^{-}+\mathrm{CH}_{3} \mathrm{OCH}_{2} \mathrm{CO}_{2} \mathrm{H}
$$

\section{Results}

Four structurally similar organic acids $\left(\mathrm{HA}_{\mathrm{i}}\right)$ with known gas-phase acidities were selected as the references: $\mathrm{CH}_{3} \mathrm{OCH}_{2} \mathrm{CO}_{2} \mathrm{H}, \mathrm{CH}_{3} \mathrm{NHCH}_{2} \mathrm{CO}_{2} \mathrm{H}, \mathrm{CH}_{3} \mathrm{ClCHCO}_{2} \mathrm{H}$, and $\mathrm{CH}_{3} \mathrm{BrCHCO}_{2} \mathrm{H}$. These molecules are simple carboxylic acids with different hetero-atoms attached to the $\alpha$-carbon of the carboxyl group. The gas-phase acidities of the references are in the range of $342-337 \mathrm{kcal} / \mathrm{mol}[7,8$, 30], from the least acidic $\left(\mathrm{CH}_{3} \mathrm{OCH}_{2} \mathrm{CO}_{2} \mathrm{H}\right)$ to the most acidic $\left(\mathrm{CH}_{3} \mathrm{BrCHCO}_{2} \mathrm{H}\right)$, Table 1 . The proton-bound 
Table 1. Thermochemical quantities for the reference acids

\begin{tabular}{|c|c|c|c|c|}
\hline Reference acid & $\begin{array}{c}\Delta H_{\text {acid }}, \text { expt }^{a} \\
(\mathrm{kcal} / \mathrm{mol})\end{array}$ & $\begin{array}{c}\Delta H_{\text {acid }}, \text { calc }^{\mathrm{b}} \\
(\mathrm{kcal} / \mathrm{mol})\end{array}$ & $\begin{array}{c}\Delta G_{\text {acid }}, \text { expt }^{a} \\
(\text { kcal } / \mathrm{mol})\end{array}$ & $\begin{array}{c}\Delta S_{\text {acid }}{ }^{\mathrm{c}} \\
\text { (cal/mol } \mathrm{K})\end{array}$ \\
\hline $\mathrm{CH}_{3} \mathrm{OCH}_{2} \mathrm{CO}_{2} \mathrm{H}$ & $341.9 \pm 2.1$ & & $335.3 \pm 2.0$ & 22.1 \\
\hline $\mathrm{CH}_{3} \mathrm{NHCH}_{2} \mathrm{CO}_{2} \mathrm{H}$ & $341.5 \pm 2.1$ & 340.9 & $334.6 \pm 2.0$ & 23.1 \\
\hline $\mathrm{CH}_{3} \mathrm{ClCHCO}_{2} \mathrm{H}$ & $337.0 \pm 2.1$ & 337.4 & $330.4 \pm 2.0$ & 22.1 \\
\hline $\mathrm{CH}_{3} \mathrm{BrCHCO}_{2} \mathrm{H}$ & $336.8 \pm 2.1$ & 337.4 & $329.8 \pm 2.0$ & 23.5 \\
\hline
\end{tabular}

a Obtained from the NIST Chemistry Webbook.7,8,30

${ }^{b}$ Calculations carried out in this work.

'Derived from $\Delta H_{\text {acid }}$ and $\Delta G_{\text {acid }}$.

dimers $\left(\left[\mathrm{A} \cdot \mathrm{H} \cdot \mathrm{A}_{\mathrm{i}}\right]^{-}\right)$of deprotonated MTA (HA) with the conjugate bases of the reference acids were generated by electrospray ionization. Each of the dimers (containing the ${ }^{32} \mathrm{~S}$ isotope) was activated by collision-induced-dissociation (CID) in the collision chamber of the mass spectrometer, and two competing dissociation product ions were produced, $\mathrm{CH}_{3} \mathrm{SCH}_{2} \mathrm{CO}_{2}^{-}\left(\mathrm{A}^{-}\right)$and the deprotonated reference acid $\left(\mathrm{A}_{\mathrm{i}}^{-}\right)$. Two of the CID spectra are shown in Figure 1. Figure 1a shows the spectrum for the dissociation of $\left[\mathrm{CH}_{3} \mathrm{SCH}_{2} \mathrm{CO}_{2} \cdot \mathrm{H} \cdot \mathrm{CH}_{3} \mathrm{NHCH}_{2} \mathrm{CO}_{2}\right]^{-}$, and Figure $1 \mathrm{~b}$ shows the dissociation of $\left[\mathrm{CH}_{3} \mathrm{SCH}_{2} \mathrm{CO}_{2} \cdot \mathrm{H} \cdot \mathrm{CH}_{3}\right.$ $\left.\mathrm{ClCHCO}_{2}\right]^{-}$. In Figure 1a, the intensity of $\mathrm{CH}_{3} \mathrm{SCH}_{2} \mathrm{CO}_{2}^{-}$ is about fifteen times of that of the reference, $\mathrm{CH}_{3} \mathrm{NHCH}_{2} \mathrm{CO}_{2}^{-}$, while in Figure $1 \mathrm{~b}$, the intensity of $\mathrm{CH}_{3} \mathrm{SCH}_{2} \mathrm{CO}_{2}^{-}$is about one fifteenth of that of the reference, $\mathrm{CH}_{3} \mathrm{ClCHCO}_{2}^{-}$.

For each proton-bound dimer, the ratio of the CID product ion intensities, $\left[\mathrm{A}^{-}\right] /\left[\mathrm{A}_{\mathrm{i}}^{-}\right]$, was measured at four different collision energies $\left(E_{\mathrm{cm}}\right): 1.0,1.5,2.0$, and $2.5 \mathrm{eV}$. The results are summarized in Table 2 . The uncertainty of the data was within $\pm 5 \%$. The ratios are converted to the
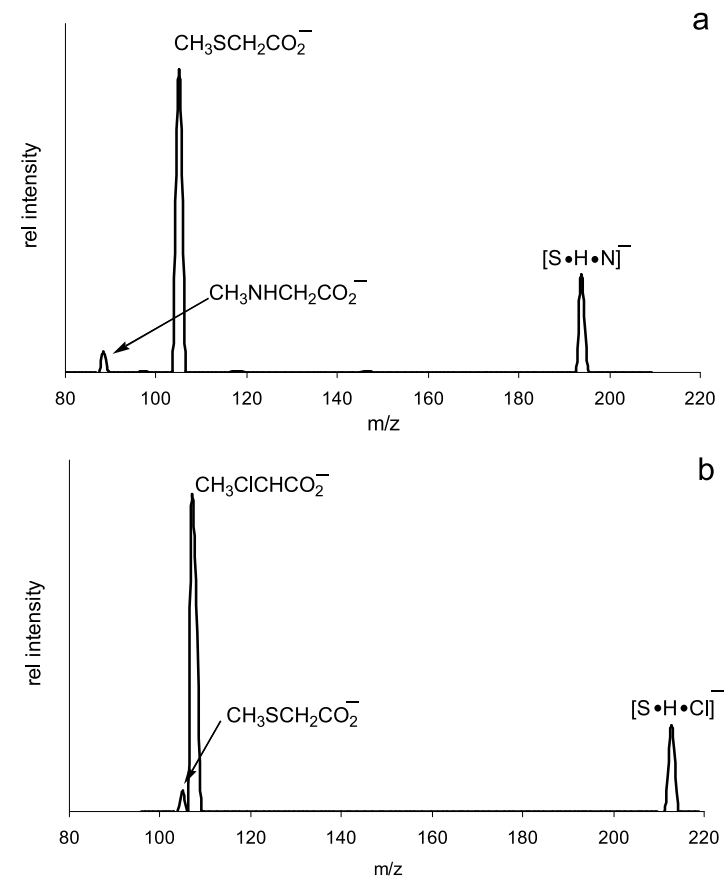

Figure 1. CID spectra of $\left[\mathrm{CH}_{3} \mathrm{SCH}_{2} \mathrm{CO}_{2} \cdot \mathrm{H} \cdot \mathrm{CH}_{3} \mathrm{NHCH}_{2} \mathrm{CO}_{2}\right]^{-}$ (a), and $\left[\mathrm{CH}_{3} \mathrm{SCH}_{2} \mathrm{CO}_{2} \cdot \mathrm{H} \cdot \mathrm{CH}_{3} \mathrm{ClCHCO}_{2}\right]^{-}$(b). The label [S.H.N $]^{-}$ and $[\mathrm{S} \cdot \mathrm{H} \cdot \mathrm{Cl}]^{-}$represent the two dimer ions. logarithms, $\ln \left(\left[\mathrm{A}^{-}\right] /\left[\mathrm{A}_{\mathrm{i}}^{-}\right]\right)$, and are plotted as a function of collision energy, Figure 2. The data points for both the proton-bound dimers with $\mathrm{CH}_{3} \mathrm{OCH}_{2} \mathrm{CO}_{2} \mathrm{H}$ and $\mathrm{CH}_{3} \mathrm{NHCH}_{2} \mathrm{CO}_{2} \mathrm{H}$ are above zero (the center line) and approach zero as the collision energy is increased. On the other hand, the data points for the proton-bound dimers with $\mathrm{CH}_{3} \mathrm{ClCHCO}_{2} \mathrm{H}$ and $\mathrm{CH}_{3} \mathrm{BrCHCO}_{2} \mathrm{H}$ are below zero and also approach zero at higher collision energies.

In order to determine the gas-phase acidity of MTA $\left(\Delta H_{\text {acid }}\right)$ using the extended kinetic method (eq 2), two thermo-kinetic graphs were generated. The first one was the plots of the logarithms of the CID product ion ratios, $\ln \left(\left[\mathrm{A}^{-}\right] /\left[\mathrm{A}_{\mathrm{i}}^{-}\right]\right)$, against corresponding $\Delta H_{\mathrm{i}}-$ $\Delta H_{\text {avg, }}$ where $\Delta H_{\text {avg }}(339.3 \pm 1.7 \mathrm{kcal} / \mathrm{mol})$ was the average gas-phase acidity of the four reference acids. The uncertainty of the average acidity was calculated as the root sum square of the random and systematic errors. The random error was treated as the averaged uncertainty of the reference acids $( \pm 2.1)$ divided by the square root of the number of the reference acids, $(2.1 / \sqrt{ } 4)=1.0 \mathrm{kcal} / \mathrm{mol}$, and the systematic error was assigned as $\sqrt{ } 2.1=1.4 \mathrm{kcal} / \mathrm{mol}$. The root sum square of the random and systematic errors yielded $\sqrt{ }\left(1.0^{2}+\right.$ $\left.1.4^{2}\right)=1.7 \mathrm{kcal} / \mathrm{mol}$. The data measured at the same collision energy were fit by a weighted linear regression with 95\% confidence level (CL), and four linear plots were generated, Figure 3. These lines have different slopes and intercepts, and cross at a single point. The slope of each line corresponds to $1 / R T_{\text {eff }}$ and the intercept corresponds to $-\left[\left(\Delta H-\Delta H_{\mathrm{avg}}\right) / R T_{\text {eff }}-\right.$ $\Delta(\Delta S) / R]$ at that particular collision energy. The values of the slopes and the intercepts along with the $T_{\text {eff }}$ derived from the slopes are summarized in Table 3 . The second thermo-kinetic graph was generated by plotting the values of $\left[\left(\Delta H-\Delta H_{\text {avg }}\right) / R T_{\text {eff }}-\Delta(\Delta S) / R\right]$ obtained from the first graph against the corresponding -1/ $R T_{\text {eff }}$, Figure 4 . Linear regression (95\% CL) of the data gives a straight line with a slope of $0.73 \pm 0.02$ and an intercept of $-0.43 \pm 0.03$. The slope of this line corresponds to $\Delta H-\Delta H_{\mathrm{avg}}$, and the intercept corresponds to $-\Delta(\Delta S) / R$. Combined with the value of $\Delta H_{\text {avg }}(339.3 \pm$ $1.7 \mathrm{kcal} / \mathrm{mol}$ ), the value of $\Delta H$ (corresponding to $\Delta H_{\text {acid }}$ of MTA) was determined to be $340.0+1.7 \mathrm{kcal} / \mathrm{mol}$. The average entropy difference, $\Delta(\Delta S)$, was determined to be $0.8 \mathrm{cal} / \mathrm{mol} \mathrm{K}$, corresponding to $0.2 \mathrm{kcal} / \mathrm{mol}$ of the entropy contribution, $[T \Delta(\Delta S)]$, at $298 \mathrm{~K}$.

The entropy term, $(\Delta(\Delta S))$, determined from the ex- 
Table 2. Product ion ratios $\left(\left[\mathrm{A}^{-}\right] /\left[\mathrm{A}_{\mathrm{i}}^{-}\right]\right)$of dissociation of proton-bound dimers at four different centre-of-mass collision energies (with $\pm 5 \%$ of uncertainty)

\begin{tabular}{lrrrr}
\hline Reference acid & $1.0 \mathrm{eV}$ & $1.5 \mathrm{eV}$ & $2.0 \mathrm{eV}$ & $2.5 \mathrm{eV}$ \\
\hline \hline $\mathrm{CH}_{3} \mathrm{OCH}_{2} \mathrm{CO}_{2} \mathrm{H}$ & 13.35 & 10.62 & 8.32 & 6.52 \\
$\mathrm{CH}_{3} \mathrm{NHCH}_{2} \mathrm{CO}_{2} \mathrm{H}$ & 14.66 & 12.34 & 9.42 & 8.54 \\
$\mathrm{CH}_{3} \mathrm{ClCHCO}_{2} \mathrm{H}$ & 0.06 & 0.07 & 0.10 & 0.12 \\
$\mathrm{CH}_{3} \mathrm{BrCHCO}_{2} \mathrm{H}$ & 0.01 & 0.02 & 0.04 & 0.05 \\
\hline
\end{tabular}

tended kinetic method was small. It is reasonable to assume that the standard kinetic method, eqs 3 and 4, is valid for determining the gas-phase acidity of MTA $\left(\Delta H_{\text {acid }}\right.$ and $\left.\Delta G_{\text {acid }}\right)$ using the chosen set of reference acids. To test this, we determined $\Delta H_{\text {acid }}$ using eq 3 by plotting $\ln \left(\left[\mathrm{A}^{-}\right] /\left[\mathrm{A}_{\mathrm{i}}^{-}\right]\right)$against $\Delta H_{\mathrm{i}}$. Linear regression of the data gives a straight line with the slope of $1 / R T_{\text {eff }}$ and the

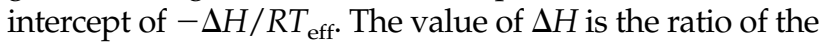
negative intercept to the slope. Four linear plots were generated from the data collected at four different collision energies and four similar values of $\Delta H(339.8,339.7$, 339.9 , and $339.7 \mathrm{kcal} / \mathrm{mol}$ ) were obtained, with an averaged value of $339.8 \mathrm{kcal} / \mathrm{mol}$. Based on the error analysis similar to that of the extended method, we assign \pm 1.7 $\mathrm{kcal} / \mathrm{mol}$ (the average uncertainty of the reference acids) as the uncertainty. This gives the gas-phase acidity of MTA $\left(\Delta H_{\text {acid }}\right)$ to be $339.8 \pm 1.7 \mathrm{kcal} / \mathrm{mol}$, which is essentially the same as that obtained from the extended kinetic method $(340.0+1.7 \mathrm{kcal} / \mathrm{mol})$.

Using the similar approach, we determined the free energy of deprotonation $\left(\Delta G_{\text {acid }}\right)$ of MTA using eq 4 . The plot of $\ln \left(\left[\mathrm{A}^{-}\right] /\left[\mathrm{A}_{\mathrm{i}}^{-}\right]\right)$versus $\Delta G_{\mathrm{i}}$ (the gas-phase acidity of the reference acids) gives a straight line with the slope of $1 / R T_{\text {eff }}$ and the intercept of $-\Delta G / R T_{\text {eff }}$. The value of $\Delta G$ was the ratio of the negative intercept to the slope. Four linear plots associated with the four collision energies are shown in Figure 5. Four values of $\Delta G$ $(333.3,333.2,332.9$ and $332.8 \mathrm{kcal} / \mathrm{mol})$ were obtained and the average value was $333.0 \mathrm{kcal} / \mathrm{mol}$. We assign $\pm 1.7 \mathrm{kcal} / \mathrm{mol}$ (the average uncertainty of the reference acids) as the uncertainty and the free energy of deprotonation for MTA $\left(\Delta G_{\text {acid }}\right)$ was determined to be $333.0 \pm$ $1.7 \mathrm{kcal} / \mathrm{mol}$. With the enthalpy and the free energy for MTA available (determined from the standard kinetic method), we estimated the entropy of acidity of MTA $\left(\Delta S_{\text {acid }}\right)$ using the thermochemical relationship: $\Delta S_{\text {acid }}=$ $\left(\Delta H_{\text {acid }}-\Delta G_{\text {acid }}\right) / R T$, where $T=298 \mathrm{~K}$. A value of 22.8 $\mathrm{kal} / \mathrm{mol} \mathrm{K}$ was obtained (we did not assign an uncertainty to this value).

The structures and the thermochemical properties (sum of the electronic enthalpies at $298 \mathrm{~K}$ ) of MTA and the reference acids were calculated using the density function theory at the B3LYP/6-31 $+\mathrm{G}^{*}$ level. The reference acids all have the similar structures with each other and also have the structures similar to that of MTA. In particular, MTA resembles $\mathrm{CH}_{3} \mathrm{OCH}_{2} \mathrm{CO}_{2} \mathrm{H}$ in both the neutral and the deprotonated forms. Theoretical predictions of the gas-phase acidity of MTA were calculated using the isodesmic reaction with $\mathrm{CH}_{3} \mathrm{OCH}_{2} \mathrm{CO}_{2} \mathrm{H}$ (eq 5) as the reference standard. In order to test the computational method, we calculated the gas-phase acidities of the references acids and the results are summarized in Table 1. The calculated acidities for the reference acids agree well with the experimental values obtained from literature. Using the same procedure, we calculated the acidity of MTA to be $338.9 \mathrm{kcal} / \mathrm{mol}$. For comparison, we also calculated the gas-phase acidities of $\mathrm{C}_{6} \mathrm{H}_{5} \mathrm{OCH}_{2} \mathrm{CO}_{2} \mathrm{H}$ and $\mathrm{C}_{6} \mathrm{H}_{5} \mathrm{SCH}_{2} \mathrm{CO}_{2} \mathrm{H}$ at the same level of theory and the values obtained were 338.6 and $335.7 \mathrm{kcal} / \mathrm{mol}$, respectively.

\section{Discussion}

The gas-phase acidity of MTA was determined by using the Cooks' kinetic method with the consideration of the entropy effect. The value of $\Delta H_{\text {acid }}$ was determined to be $340.0 \pm 1.7 \mathrm{kcal} / \mathrm{mol}$ by using the extended kinetic method. Standard kinetic method yielded $339.8 \pm 1.7$ and $333.0 \pm 1.7 \mathrm{kcal} / \mathrm{mol}$ for the values of $\Delta H_{\text {acid }}$ and $\Delta G_{\text {acid }}$ respectively. The entropy of the acid dissociation, $\Delta S_{\text {acid }}$ was estimated to be $22.8 \mathrm{cal} / \mathrm{mol} \mathrm{K}$.

One major concern involved in the kinetic method is the entropic effect [10, 20-23, 31]. For dissociation of a proton-bound dimer, the observed branching ratio does not only depend on the relative acidity of the pair of acids that form the dimer, but also on the density of states at the transition states of the two dissociation channels [23, 32]. The density of states corresponds to the entropy of activation [22]. The two dissociation channels can be viewed as two competing proton transfer reactions (Scheme 1).

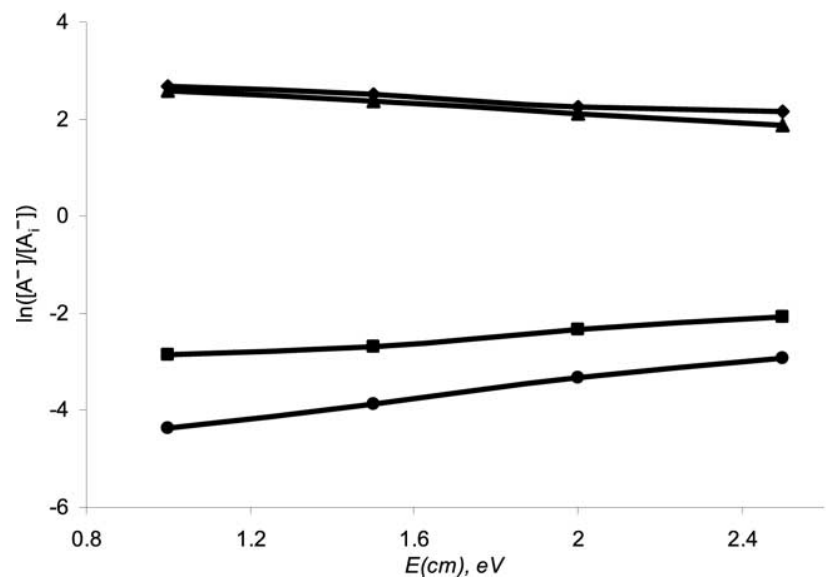

Figure 2. Plots of $\ln \left(\left[\mathrm{A}^{-}\right] /\left[\mathrm{A}_{\mathrm{i}}^{-}\right]\right)$versus $E_{\mathrm{cm}}$ for $\mathrm{A}_{\mathrm{i}}^{-}$of $\mathrm{CH}_{3} \mathrm{NHCH}_{2} \mathrm{COA}_{2}^{-}$(filled diamond), $\mathrm{CH}_{3} \mathrm{OCH}_{2} \mathrm{CO}_{2}^{-}$(filled triangle), $\mathrm{CH}_{3} \mathrm{ClCHCO}_{2}^{-}$(filled square) and $\mathrm{CH}_{3} \mathrm{BrCHCO}_{2}^{-}$(filled circle). 


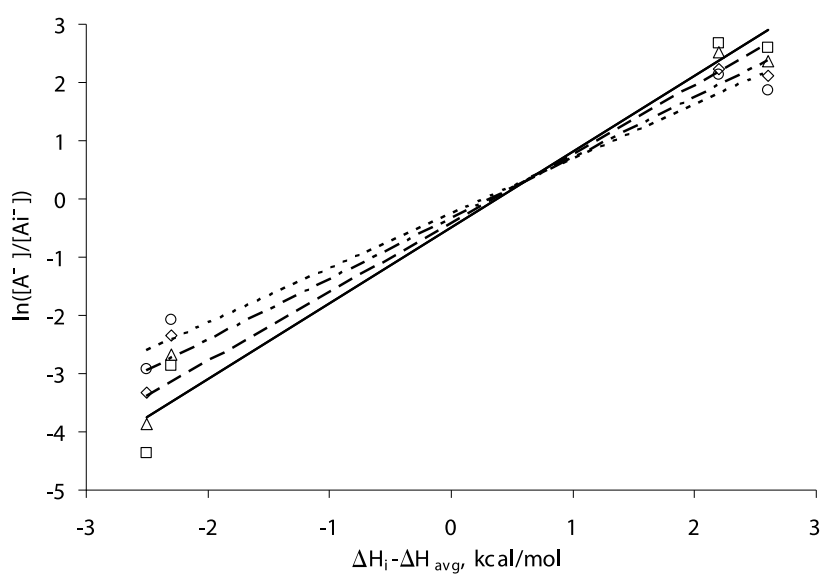

Figure 3. Plots of $\ln \left(\left[\mathrm{A}^{-}\right] /\left[\mathrm{A}_{\mathrm{i}}^{-}\right]\right)$versus $\Delta H_{\mathrm{i}}-\Delta H_{\mathrm{avg}}$ at four collision energies: $1.0 \mathrm{eV}$ (long dashes), $\mathrm{R}^{2}=0.98 ; 1.5 \mathrm{eV}$ (short dashes), $R^{2}=0.98 ; 2.0 \mathrm{eV}$ (dash dot dash), $R^{2}=0.98$ and $2.5 \mathrm{eV}$ (dots), $\mathrm{R}^{2}=0.98$.

Therefore, the activation entropies are directly related to the structures of the two components of the proton-bound dimer, $\mathrm{AH}$ versus $\mathrm{HA}_{\mathrm{i}}$ and $\mathrm{A}^{-}$versus $\mathrm{A}_{\mathrm{i}}^{-}$. Similar structures would have similar activation entropies. The reference acids used in this study are simple carboxylic acids with different heteroatoms attached to the $\alpha$-carbon next to the carboxyl group. Theoretical calculations perform at the B3LYP/6-31 + $G^{*}$ level show that the structures of the neutral reference acids and MTA are similar to each other, and no significant structure change upon deprotonation occurs. In particular, the structure of MTA resembles that of $\mathrm{CH}_{3} \mathrm{OCH}_{2} \mathrm{CO}_{2} \mathrm{H}$. For the series of proton-bound dimers used for this study, the entropy difference between the two dissociation channels is expected to be small. In fact, the average entropy difference derived from the extended kinetic method is $0.8 \mathrm{cal} / \mathrm{mol} \mathrm{K}$, corresponding to 0.2 $\mathrm{kcal} / \mathrm{mol}$ of energy $(T \Delta(\Delta S))$ at $298 \mathrm{~K}$. Recent experimental and theoretical studies show that the derived relative entropies from the extended kinetic method were systematically underestimated by $20-40 \%$ [33-36]. If we consider a $30 \%$ error in the derived relative entropy, the value of $\Delta(\Delta S)$ would be $1.1 \mathrm{cal} / \mathrm{mol} \mathrm{K}$, or about $0.3 \mathrm{kcal} / \mathrm{mol}$ of entropy contribution. This means that if the entropic term were ignored, then the measured acidity would be off by $0.3 \mathrm{kcal} / \mathrm{mol}$. Indeed, the $\Delta H_{\text {acid }}$ value determined using the standard kinetic method is $0.2 \mathrm{kcal} / \mathrm{mol}$ lower than that obtained from the extended kinetic method. Compared to the uncertainty assigned to the measured acidity, the entropic contribution in this case is insignificant.

The similarity in the activation entropy of the two dissociation channels is also reflected in the plot of $\ln \left(k / k_{\mathrm{i}}\right)$ versus $E_{\mathrm{cm}}$. According to eq 1 , the value of $\ln \left(k / k_{\mathrm{i}}\right)$ is inversely proportional to $T_{\text {eff. If }} \Delta(\Delta S)$ is zero, then the absolute value of $\ln \left(k / k_{\mathrm{i}}\right)$ would be smaller as $T_{\text {eff }}$ is increased. The effective temperature ( $\left.T_{\text {eff }}\right)$ is a measure of the internal energy of the proton-bound dimer and has a positive dependence on the collision energy. A higher collision energy corresponds to a higher $T_{\text {eff }}[20,31]$. In Figure 2, the logarithms of the product ion ratios (corresponding to $\left.\ln \left(k / k_{\mathrm{i}}\right)\right)$ for all of the proton-bound dimers approach zero as the collision energy is increased, indicating that the term $\Delta(\Delta S)$ is negligible. This result agrees with the studies by Fenselau and coworkers [11]. Note in Figure 2 that the line with $\mathrm{CH}_{3} \mathrm{NHCH}_{2} \mathrm{CO}_{2} \mathrm{H}$ is above that of $\mathrm{CH}_{3} \mathrm{OCH}_{2} \mathrm{CO}_{2} \mathrm{H}$, suggesting that the relative deprotonation energy of $\mathrm{CH}_{3} \mathrm{OCH}_{2} \mathrm{CO}_{2} \mathrm{H}$ is smaller than that of $\mathrm{CH}_{3} \mathrm{NHCH}_{2} \mathrm{CO}_{2} \mathrm{H}$. We performed CID experiments on the proton-bound dimer, $\left[\mathrm{CH}_{3} \mathrm{OCH}_{2} \mathrm{CO}_{2}\right.$. $\left.\mathrm{H} \cdot \mathrm{CH}_{3} \mathrm{NHCH}_{2} \mathrm{CO}_{2}\right]^{-}$, at several collision energies. In deed the peak of $\mathrm{CH}_{3} \mathrm{OCH}_{2} \mathrm{CO}_{2}^{-}$was slightly (5\%) higher than that for $\mathrm{CH}_{3} \mathrm{NHCH}_{2} \mathrm{CO}_{2}^{-}$.

The $\Delta H_{\text {acid }}$ of MTA was determined to be 340.0 $\mathrm{kcal} / \mathrm{mol}$. MTA has the acidity between that of $\mathrm{CH}_{3} \mathrm{NHCH}_{2} \mathrm{CO}_{2} \mathrm{H} \quad(341.5 \mathrm{kcal} / \mathrm{mol})$ [30] and $\mathrm{CH}_{3} \mathrm{ClCHCO}_{2} \mathrm{H} \quad(337.0 \mathrm{kcal} / \mathrm{mol})$ [8]. The relative acidity of MTA compared to the two reference acids can easily be seen in Figure 1. Dissociation of $\left[\mathrm{CH}_{3} \mathrm{SCH}_{2} \mathrm{CO}_{2}\right.$. $\left.\mathrm{H} \cdot \mathrm{CH}_{3} \mathrm{NHCH}_{2} \mathrm{CO}_{2}\right]^{-}$produces more $\mathrm{CH}_{3} \mathrm{SCH}_{2} \mathrm{CO}_{2}^{-}$ than $\mathrm{CH}_{3} \mathrm{NHCH}_{2} \mathrm{CO}_{2}^{-}$(Figure 1a), suggesting that $\mathrm{CH}_{3} \mathrm{SCH}_{2} \mathrm{CO}_{2} \mathrm{H}$ is a stronger acid than $\mathrm{CH}_{3} \mathrm{NHCH}_{2} \mathrm{CO}_{2} \mathrm{H}$. While dissociation of $\left[\mathrm{CH}_{3} \mathrm{SCH}_{2} \mathrm{CO}_{2}\right.$. $\left.\mathrm{H} \cdot \mathrm{CH}_{3} \mathrm{ClCHCO}_{2}\right]^{-}$yields more $\mathrm{CH}_{3} \mathrm{ClCHCO}_{2}^{-}$than $\mathrm{CH}_{3} \mathrm{SCH}_{2} \mathrm{CO}_{2}^{-}$(Figure 1b), indicating that $\mathrm{CH}_{3} \mathrm{SCH}_{2} \mathrm{CO}_{2} \mathrm{H}$ is a weaker acid than $\mathrm{CH}_{3} \mathrm{ClCHCO}_{2} \mathrm{H}$. We also compared the relative acidity of MTA with an additional carboxylic acid, $\mathrm{ClCH}_{2} \mathrm{CH}_{2} \mathrm{CO}_{2} \mathrm{H}(340.8 \pm$ $2.7 \mathrm{kcal} / \mathrm{mol}$ ) [8]. The CID spectrum (not shown) of $\left[\mathrm{CH}_{3} \mathrm{SCH}_{2} \mathrm{CO}_{2} \cdot \mathrm{H} \cdot \mathrm{ClCH}_{2} \mathrm{CHCO}_{2}\right]^{-}$shows that the peak corresponds to $\mathrm{CH}_{3} \mathrm{SCH}_{2} \mathrm{CO}_{2}^{-}$is about one forth of that of $\mathrm{ClCH}_{2} \mathrm{CHCO}_{2}^{-}$, suggesting that MTA is a weaker acid than $\mathrm{ClCH}_{2} \mathrm{CH}_{2} \mathrm{CO}_{2} \mathrm{H}$. Since the literature value of the gas-phase acidity of $\mathrm{ClCH}_{2} \mathrm{CH}_{2} \mathrm{CO}_{2} \mathrm{H}$ has a relatively larger uncertainty $( \pm 2.7 \mathrm{kcal} / \mathrm{mol})$, we did not include this molecule as a reference in the data analysis.

This study shows that MTA and $\mathrm{CH}_{3} \mathrm{OCH}_{2} \mathrm{CO}_{2} \mathrm{H}$ have an inverted order of acidity in the gas-phase compared to that in solution. In aqueous solution, the $\mathrm{p} K_{\mathrm{a}}$ values for

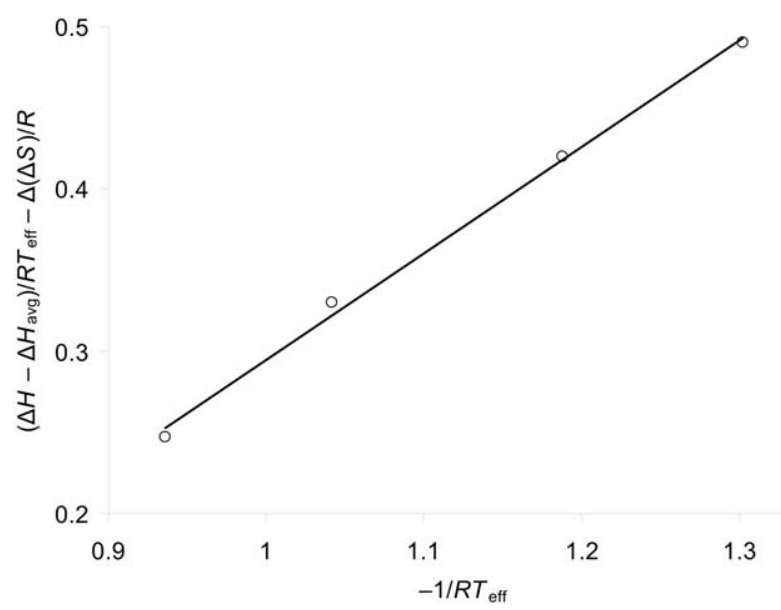

Figure 4. Plot of $\left(\Delta H-\Delta H_{\text {avg }}\right) / R T_{\text {eff }}-\Delta(\Delta S) / R$ versus $-1 / R T_{\text {eff }}$ $\mathrm{R}^{2}=0.99$. 
Table 3. Slopes and intercepts obtained from weighted linear regression of the experimental data, where the uncertainties refer to $95 \%$ conference level

\begin{tabular}{cccr}
\hline $\mathrm{E}_{\mathrm{cm},} \mathrm{eV}$ & $\left(1 / R T_{\text {eff }}\right)^{\mathrm{a}}$ & {$\left[\left(\Delta H-\Delta H_{\text {avg }}\right) / R T_{\text {eff }}-\Delta(\Delta S) / R\right]^{\mathrm{b}}$} & $T_{\text {eff }} \mathrm{K}$ \\
\hline \hline 1.0 & $1.33 \pm 0.14$ & $0.54 \pm 0.35$ & $378 \pm 39$ \\
1.5 & $1.21 \pm 0.12$ & $0.45 \pm 0.29$ & $415 \pm 41$ \\
2.0 & $1.06 \pm 0.10$ & $0.35 \pm 0.24$ & $474 \pm 44$ \\
2.5 & $0.95 \pm 0.09$ & $0.25 \pm 0.22$ & $527 \pm 49$ \\
\hline
\end{tabular}

aSlope of eq 2.

${ }^{b}$ Negative intercept of eq 2 . The relatively larger uncertainties in $\left[\left(\Delta H-\Delta H_{\text {avg }}\right) / R T_{\text {eff }}-\Delta(\Delta S) / R\right]$ were the results of the weighted linear regression.

$\mathrm{CH}_{3} \mathrm{OCH}_{2} \mathrm{CO}_{2} \mathrm{H}$ and $\mathrm{CH}_{3} \mathrm{SCH}_{2} \mathrm{CO}_{2} \mathrm{H}$ are 3.5 and 3.7 , and in dimethoxyethane (DME) the $\mathrm{pK}_{\mathrm{a}}$ values are 8.3 and 8.8, respectively [6]. Ionization leads to the conjugate bases: $\mathrm{CH}_{3} \mathrm{SCH}_{2} \mathrm{CO}_{2}^{-}$and $\mathrm{CH}_{3} \mathrm{OCH}_{2} \mathrm{CO}_{2}^{-}$. In solution, the conjugate bases are stabilized by the interaction with the bulk solvent. The slightly greater acidity of methoxyacetic acid in solution is mainly because of the stronger electron withdrawing effect (inductive effect) of the $\mathrm{CH}_{3} \mathrm{O}$ group that would assist the acid ionization. While in the gasphase, the solvent effect is absent. The stability of the charged conjugate base becomes a dominate factor in determining the acidity of the molecule [5, 37-39]. In general, higher polarizable groups have higher capabilities in stabilizing charges [37, 38]. Sulfur is larger and more polarizable than oxygen. The negative charge in $\mathrm{CH}_{3} \mathrm{SCH}_{2} \mathrm{CO}_{2}^{-}$would be stabilized more than that in $\mathrm{CH}_{3} \mathrm{OCH}_{2} \mathrm{CO}_{2}^{-}$. Therefore MTA would be a stronger acid than methoxyacetic acid in the gas-phase. In addition, the possible intramolecular hydrogen bond between the carboxyl group and the methoxy oxygen would increase the deprotonation energy (or decrease the gas-phase acidity) of $\mathrm{CH}_{3} \mathrm{OCH}_{2} \mathrm{CO}_{2} \mathrm{H}$. The reversed acidity order was also found between $\mathrm{C}_{6} \mathrm{H}_{5} \mathrm{OCH}_{2} \mathrm{CO}_{2} \mathrm{H}$ and $\mathrm{C}_{6} \mathrm{H}_{5} \mathrm{SCH}_{2} \mathrm{CO}_{2} \mathrm{H}$. Our calculations show that $\mathrm{C}_{6} \mathrm{H}_{5} \mathrm{SCH}_{2} \mathrm{CO}_{2} \mathrm{H}\left(\Delta H_{\text {acid }}=\right.$ $335.7 \mathrm{kcal} / \mathrm{mol}$ ) is a stronger gas-phase acid than $\mathrm{C}_{6} \mathrm{H}_{5} \mathrm{OCH}_{2} \mathrm{CO}_{2} \mathrm{H}\left(\Delta H_{\text {acid }}=338.6 \mathrm{kcal} / \mathrm{mol}\right)$. While in DME, $\mathrm{C}_{6} \mathrm{H}_{5} \mathrm{OCH}_{2} \mathrm{CO}_{2} \mathrm{H}\left(\mathrm{pK} \mathrm{a}_{\mathrm{a}}=8.3\right)$ is a stronger acid than $\mathrm{C}_{6} \mathrm{H}_{5} \mathrm{SCH}_{2} \mathrm{CO}_{2} \mathrm{H}(\mathrm{pK}$

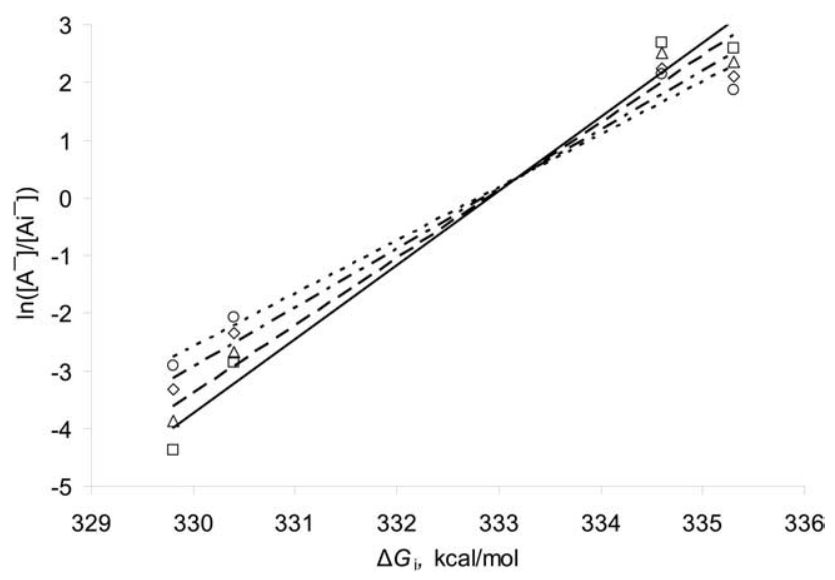

Figure 5. Plots of $\ln \left(\left[\mathrm{A}^{-}\right] /\left[\mathrm{A}_{\mathrm{i}}^{-}\right]\right)$versus $\Delta G_{\mathrm{i}}$ at four collision energies: $1.0 \mathrm{eV}$ (long dashes), $\mathrm{R}^{2}=0.98 ; 1.5 \mathrm{eV}$ (short dashes), $\mathrm{R}^{2}$ $=0.98 ; 2.0 \mathrm{eV}$ (dash dot dash), $\mathrm{R}^{2}=0.98$ and $2.5 \mathrm{eV}$ (dots), $\mathrm{R}^{2}=$ 0.98 . analysis, both the less polarizable oxygen and the possible intromolecular hydrogen bond are responsible for the lower gas-phase acidity of $\mathrm{C}_{6} \mathrm{H}_{5} \mathrm{OCH}_{2} \mathrm{CO}_{2} \mathrm{H}$.

Since the entropy term is insignificant in this case, the free energy of deprotonation $\left(\Delta G_{\text {acid }}\right)$ can be determined using the standard kinetic method (eq 4). The value of $333.0 \mathrm{kcal} / \mathrm{mol}$ determined for MTA is smaller than that of $\mathrm{CH}_{3} \mathrm{NHCH}_{2} \mathrm{CO}_{2} \mathrm{H}\left(\Delta G_{\text {acid }}=334.6 \mathrm{kcal} /\right.$ mol) and greater than that of $\mathrm{CH}_{3} \mathrm{ClCHCO}_{2} \mathrm{H}\left(\Delta \mathrm{G}_{\text {acid }}=\right.$ $330.4 \mathrm{kcal} / \mathrm{mol})$, in agreement with the acidity scale of $\Delta H_{\text {acid }}$ for these molecules. The entropy of deprotonation for MTA $\left(\Delta S_{\text {acid }}=22.8 \mathrm{cal} / \mathrm{mol} \mathrm{K}\right)$ derived from the values of $\Delta H_{\text {acid }}$ and $\Delta G_{\text {acid }}$ is comparable to that of the structure similar $\mathrm{CH}_{3} \mathrm{OCH}_{2} \mathrm{CO}_{2} \mathrm{H}(22.1 \mathrm{cal} / \mathrm{mol} \mathrm{K})$.

Theoretical predictions of the gas-phase acidity were calculated at the B3LYP/6-31 $+\mathrm{G}^{*}$ level using the isodesmic reaction with $\mathrm{CH}_{3} \mathrm{OCH}_{2} \mathrm{CO}_{2} \mathrm{H}$ as the reference standard (eq 5). The computational method was tested by calculating the gas-phase acidities of the reference acids. The results listed in Table 2 show good agreements between the theoretical predictions and the experimental literature values. The same computational method predicted the gas-phase acidity of MTA to be $338.9 \mathrm{kcal} / \mathrm{mol}$, in good agreement with the measured acidity of $340.0 \pm$ $1.7 \mathrm{kcal} / \mathrm{mol}$.

\section{Conclusions}

We determined the gas-phase acidity $\left(\Delta H_{\text {acid }}=340.0 \pm\right.$ $1.7 \mathrm{kcal} / \mathrm{mol}$ ) of MTA using the extended as well as the standard Cooks' kinetic method. The entropic contribution is insignificant in this case and can be ignored. We also determined the free energy of deprotonation $\left(\Delta G_{\text {acid }}\right.$ $=333.0 \pm 1.7 \mathrm{kcal} / \mathrm{mol}$ ) of MTA using the standard kinetic method. The entropy of deprotonation $\left(\Delta S_{\text {acid }}=\right.$ $22.8 \mathrm{cal} / \mathrm{mol} \mathrm{K}$ ) of MTA was derived from the values of $\Delta H_{\text {acid }}$ and $\Delta G_{\text {acid }}$. On the gas-phase acidity scale, MTA has a stronger acidity than that of $\mathrm{CH}_{3} \mathrm{NHCH}_{2} \mathrm{CO}_{2} \mathrm{H}$ and a weaker one than that of $\mathrm{CH}_{3} \mathrm{ClCHCO}_{2} \mathrm{H}$. The entropy of deprotonation of MTA is similar to that of $\mathrm{CH}_{3} \mathrm{OCH}_{2} \mathrm{CO}_{2} \mathrm{H}$. Although in solution MTA is a weaker acid than $\mathrm{CH}_{3} \mathrm{OCH}_{2} \mathrm{CO}_{2} \mathrm{H}$, in the gas-phase MTA is a stronger one.

\section{Acknowledgments}

This research was partially supported by the SAAG grant from the University of the Pacific. $\mathrm{CP}$ thanks the Deans' Undergraduate 
Research Award from Pacific. The authors thank the support from the Chemistry and the Biology departments at Pacific. They also thank Lisa Perkins from Varian for the help in using the Varian 1200L and Dr. E. M Strittmatter from the Pacific Northwest National Laboratory for providing the program to perform the linear regression analysis.

\section{References}

1. Trost, B. M.; Tamaru, Y. 2-Methylthioacetic Acid and Diethyl Malonate as Acyl Anion Equivalents Synthesis of Juvabione. Tetrahedron Lett. 1975, 3797-3800.

2. Trost, B. M.; Tamaru, Y. New Synthetic Reactions. Oxidative Decarboxylation of a-Methylthiocarboxylic Acids, New Approach to Acyl Anion and Ketene Synthons. J. Am. Chem. Soc. 1977, 99, 3101-3113.

3. Gawandi, V. B.; Mohan, H.; Mittal, J. P. Evidence for the Role of Electron-Withdrawing Power of Functional Groups and $[\mathrm{H}+]$ for Electron-Transfer Reaction in Substituted Alkyl Sulfides. J. Phys. Chem. A 2000, 104, 11877-11884.

4. Huynh-Ba, T.; Matthey-Doret, W.; Fay, L. B.; Rhlid, R. B. Generation of Thiols by Biotransformation of Cysteine-Aldehyde Conjugates with Baker's Yeast. J. Agric. Food Chem. 2003, 51, 3629-3635.

5. Headley, A. D.; McMurry, M. E.; Starnes, S. D. Effects of Substituents on the Acidity of Acetic Acids. J. Org. Chem. 1994, 59, 1863-1866.

6. Headley, A. D.; Starnes, S. D.; Wilson, L. Y.; Famini, G. R. Analysis of Solute/Solvent Interactions for the Acidity of Acetic Acids by Theoretical Descriptors. J. Org. Chem. 1994, 59, 8040-8046.

7. Linstrom, P. J.; Mallard, W. G., Eds. NIST Chemistry Webbook, NIST Standard Reference Database Number 69, March 2003; National Institue of Standards and Technology: March 2003.

8. Caldwell, G. W.; Renneboog, R.; Kebarle, P. Gas-Phase Acidities of Aliphatic Carboxylic Acids, Based on Measurements of Proton-Transfer Equilibria. Can. J. Chem. 1989, 67, 611-618.

9. Cooks, R. G.; Patrick, J. S.; Kotiaho, T.; McLuckey, S. A. Thermochemical Determinations by the Kinetic Method. Mass Spectrom. Rev. 1994, 13, 287-339.

10. Cooks, R. G.; Wong, P. S. H. Kinetic Method of Making Thermochemical Determinations: Advances and Applications. Acc. Chem. Res. 1998, 31, 379-386.

11. Cheng, X.; Wu, Z.; Fenselau, C. Collision Energy Dependence of Proton-Bound Dimer Dissociation: Entropy Effects, Proton Affinities, and Intramolecular Hydrogen-Bonding in Protonated Peptides. J. Am. Chem. Soc. 1993, 115, 4844-4848.

12. Cerda, B. A.; Wesdemiotis, $\mathrm{C}$. $\mathrm{Li}+, \mathrm{Na}+$, and $\mathrm{K}+$ Binding to the DNA and RNA Nucleobases. Bond Energies and Attachment Sites from the Dissociation of Metal Ion-Bound Heterodimers. J. Am. Chem. Soc. 1996, 118, 11884-11892.

13. Williams, T. I.; Denault, J. W.; Cooks, R. G. Proton Affinity of Deuterated Acetonitrile Estimated by the Kinetic Method with Full Entropy Analysis. Int. J. Mass Spectrom. 2001, 210/211, 133-146.

14. Hahn, I.-S.; Wesdemiotis, C. Protonation Thermochemistry of b-Alanine an Evaluation of Proton Affinities and Entropies Determined by the Extended Kinetic Method. Int. J. Mass Spectrom. 2003, 222, 465-479.

15. Schroeder, O. E.; Andriole, E. J.; Carver, K. L.; Colyer, K. E.; Poutsma, J. C. Proton Affinity of Lysine Homologues from the Extended Kinetic Method. J. Phys. Chem. A 2004, 108, 326-332.

16. Wenthold, P. G. Determination of the Proton Affinities of Bromoand Iodoacetonitrile Using the Kinetic Method with Full Entropy Analysis. J. Am. Soc. Mass Spectrom. 2000, 11, 601-605.
17. Mirza, S. P.; Prabhakar, S.; Vairamani, M. Estimation of Proton Affinity of Proline and Tryptophan under Electrospray Ionization Conditions Using the Extended Kinetic Method. Rapid Commun. Mass Spectrom. 2001, 15, 957-962.

18. Tsang, Y.; Siu, F. M.; Ho, C. S.; Ma, N. L.; Tsang, C. W. Experimental Validation of Theoretical Potassium and Sodium Cation Affinities of Amides by Mass Spectrometric Kinetic Method Measurements. Rapid Commun. Mass Spectrom. 2004, 18, 345-355.

19. Zheng, X.; Cooks, R. G. Thermochemical Determinations by the Kinetic Method with Direct Entropy Correction. J. Phys. Chem. A 2002, 106, 9939-9946.

20. Drahos, L.; Vekey, K. How Closely Related are the Effective and the Real Temperature. J. Mass Spectrom. 1999, 34, 79-84.

21. Armentrout, P. B. Is the Kinetic Method a Thermodynamic Method? J. Mass Spectrom. 1999, 34, 74-78.

22. Laskin, J.; Futrell, J. H. The Theoretical Basis of the Kinetic Method from the Point of View of Finite Heat Bath Theory. J. Phys. Chem. A 2000, 104, 8829-8837.

23. Ervin, K. M. Microcanonical Analysis of the Kinetic Method. The Meaning of the "Apparent Entropy". J. Am. Soc. Mass Spectrom. 2002, 13, 435-452.

24. Norrman, K.; McMahon, T. B. Relationship Between Effective Temperature of Thermalized Ions and Ion Source Temperature. Int. J. Mass Spectrom. 1998, 176, 87-97.

25. Cooks, R. G.; Koskinen, J. T.; Thomas, P. D. The Kinetic Method of Making Thermochemical Determinations. J. Mass Spectrom. 1999, 34, 85-92.

26. Armentrout, P. B. Entropy Measurements and the Kinetic Method: A Statistically Meaningful Approach. J. Am. Soc. Mass Spectrom. 2000, 11, 371-379.

27. Cooks, R. G.; Kruger, T. L. Intrinsic Basicity Determination Using Metastable Ions. J. Am. Chem. Soc. 1977, 99, 1279-1281.

28. McLuckey, S. A.; Cameron, D.; Cooks, R. G. Proton Affinities from Dissociations of Proton-Bound Dimers. J. Am. Chem. Soc. 1981, 103, 1313-1317.

30. Locke, M. J.; McIver, R. T., Jr. Effect of Solvation on the Acid/ Base Properties of Glycine. J. Am. Chem. Soc. 1983, 105, 42264232.

31. Drahos, L.; Vekey, K. Entropy Evaluation Using the Kinetic Method: Is It Feasible?. J. Mass Spectrom. 2003, 38, 1025-1042.

32. Craig, S. L.; Zhong, M.; Choo, B.; Brauman, J. I. Branching Ratios in Activated Systems. J. Phys. Chem. A 1997, 101, 19-24.

33. Bouchoux, G.; Sablier, M.; Berruyer-Penaud, F. Obtaining Thermochemical Data by the Extended Kinetic Method. J. Mass Spectrom. 2004, 39, 986-997.

34. Ervin, K. M.; Armentrout, P. B. Systematic and Random Errors in Ion Affinities and Activation Entropies from the Extended Kinetic Method. J. Mass Spectrom. 2004, 39, 1004-1015.

35. Drahos, L.; Peltz, C.; Vekey, K. Accuracy of Enthalpy and Entropy Determination Using the Kinetic Method Are We Approaching a Consensus? J. Mass Spectrom. 2004, 39, 1016-1024.

36. Wesdemiotis, C. Entropy Considerations in Kinetic Method Experiments. J. Mass Spectrom. 2004, 39, 998-1003.

37. Brauman, J. I.; Blair, L. K. Gas-Phase Acidities of Alcohols. Effects of Alkyl Groups. J. Am. Chem. Soc. 1968, 90, 6561-6562.

38. Hehre, W. J.; Pau, C. F.; Headley, A. D.; Taft, R. W.; Topsom, R. D. A Scale of Directional Substituent Polarizability Parameters from ab Initio Calculations of Polarizability Potentials. J. Am. Chem. Soc. 1986, 108, 1711-1712.

39. Taft, R. W. Protonic Acidities and Basicities in the Gas Phase and in Solution: Substituent and Solvent Effects. Prog. Phys. Org. Chem. 1983, 14, 247-350. 